\title{
CULTURAL REVERSAL: WHY DOES OBEDIENCE LOSE WITH THE INITIATIVE?
}

\author{
Karel SLINTÁK
}

\begin{abstract}
The article deals with the question which management philosophy is better, management philosophy based on culture HOW or management philosophy based on culture WHY. With respect to this article, author used these techniques, namely quantitative research, case methodology and literature analysis. Consequently, from the research, it can be predicted that most companies prefer a management model which inclines more towards planning, organizing and controlling than to leadership. This approach is a part of the traditional management system through which the organizational culture of "HOW" is implemented. The hidden costs of this model are apathetic staff, lost revenues and mainly work-related stress. These factors, which cause a lack of participation in the workplace, similarly lead to paralysis of innovation capabilities of most companies. They negatively affect the overall productivity of the economy and cause considerable social costs. However, there is also alternative management system based on the WHY culture. This management system, which releases initiative, creativity and enthusiasm, was investigated in the Toyota, FAVI and W. L. Gore. Author found out that these companies are able to eliminate the negative consequences of the traditional management model. The key features of this model are trust, freedom and responsibility, all three of which enrich the system with the ability to learn iteratively from one's own mistakes.
\end{abstract}

\section{KEYWORDS}

bureaucracy, freedom, leadership, management innovation, organization culture, performance, responsibility, trust.

\section{JEL CLASSIFICATION:}

M12, M14, L25

\section{INTRODUCTION}

The stimulus for writing this article was a research report by Towers Perrin (2007-2008). The aim of this study was to conduct a survey looking at employee satisfaction in eighteen countries in the world. The researchers succeeded in addressing 90,000 respondents. Subsequently, extremely surprising conclusions arose from the research. Firstly, only one fifth of employees were fully engaged, in the sense that they were willing to fulfil work tasks beyond their duties. Secondly, twofifths of employees were totally unengaged while committing work tasks. The remaining respondents were included in the category characterized by formal obedience. 
The question which arose while reading this report was: what causes such low involvement of people in the workplace? Looking at the prevailing management ideology, where profit is the only or main priority, the answer was offered directly. Companies often deal with an inability to define actual performance and to identify the factors that affect it. Most managers do not realize the connection between involvement and performance. However, there are several studies which clearly demonstrate such a connection (see Towers Perrin 2006, 2007 - 2008; Sisodia, Wolfe and Sheth 2007).

This article will extend the knowledge already revealed in previous studies. Therefore, it will address the question of efficiency and performance and subsequently uncover the management model which is taken as a consequence of the ideology of classical management. Moreover, it will attempt to map the hidden costs that this model involves. It will also propose an alternative model of management and governance that should mean a radical cultural change in the conception of the human in the workplace.

\section{THEORETICAL BACKGROUND}

There are many authors who deal with the differences between leader and manager. One of the first authors was Zaleznik (1977), who noticed that leaders and managers differ in their concepts. The manager creates processes. The leader modifies them to make work more interesting. The manager restricts freedom, while the leader does the opposite - he gives space to others in an effort to pass on to them a greater part of responsibility. According to Gardner (1990), there are six important differences between manager and leader: 1. Leader thinks in the long-term context, 2. Leader perceives relations in a wider context, 3. Work of the leader is not defined by its function, 4. Leaders focus on vision, values and motivation, 5. Leaders are able to satisfy various stakeholders, 6. Managers are dependent on organizations, organizations are dependent on leaders.

John Mariotti (1998) describes the influence of the leader and the manager on human motivation. People who are controlled, do only what they must do. Leaders are able to get from their colleagues extraordinary results. According to Drucker (1998), true leaders is a man who is able to bring up his successor who will be better than himself. Therefore, we can talk about real leadership only when a leader leaves his organization and this organization continues to prosper.

A fundamental differences between leader and manager were summarized by Warren Bennis (1990). Some of them are listed in the following table. 
Table 1 Differences between leader and manager.

\begin{tabular}{c|c}
\hline Manager & Leader \\
\hline The manager commands & The leader communicates \\
The manager administers & The Leader innovates \\
The manager is a copy & The leader is an original \\
The manager maintains & The leader develops \\
The manager focuses on systems and & The leader focuses on people. \\
The manager relies on control & The leader inspires trust \\
The manager has a short-range view & The leader has a long-range perspective. \\
The manager asks how and when & The leader asks what and why \\
The manager has his eye always on the & The leader has his eye on the horizon. \\
bottom line & The leader challenges it \\
The manager accepts the status quo & The leader is his own person. \\
The manager is the classic good soldier & The leader does the right thing. \\
The manager does things right &
\end{tabular}

(Source: own processing according to Bennis, 1990, 1994)

Some authors deal only with the leadership. Burns (1982) described in his book known as Leadership two basic approaches to leadership. Companies can apply transactional or transformational leadership. Transactional leadership means to achieve individual (separate) targets. Transformational leadership aims to achieve common goals on the basis of mutual cooperation through shared purpose.

Many authors deal also with the question whether there is a difference between management and leadership. Kotter (1990) defines these disciplines in terms of their task. Management is about managing complexity. It is a response to the emergence of large organizations. It brings order. Leadership is about managing change. It is a response to the new business environment which is characterized by increased competition and greater instability. It is a source of innovation. Pascale, quoted by Johnson (1996), understands management as a tool to exert influence and authority to achieve average results. Leadership is the effort to achieve exceptional results. Some authors, for example, Kotter (2000), Senge (1990), Weathersby (1999), come to the conclusion that management represents control, while leadership means creating a shared vision. These views are summarized by Peters (1994) who builds on the idea of Bennis, Kouzes and Posner on leadership and management. According to this author, an essential element of leadership is to develop a vision and to live with accordance to it.

Views of many authors are part of the theories that describe the management and leadership in a wider context. Selected theories are shown in the following table. 
Table 2 Theoretical background on leadership.

\begin{tabular}{|c|c|c|}
\hline Theory & Authors & Description \\
\hline Humanistic theory & $\begin{array}{lr}\text { Argyris } & (1957), \\
\text { Maslow } & (1965), \\
\text { McGregor (1960) }\end{array}$ & $\begin{array}{l}\text { Human beings have internal and } \\
\text { external motivation. The most effective } \\
\text { form of motivation is internal } \\
\text { motivation. Leadership must eliminate } \\
\text { organizational barriers and create a } \\
\text { working environment that will give } \\
\text { people the freedom to realize their } \\
\text { potential in the interest of the } \\
\text { organization. }\end{array}$ \\
\hline $\begin{array}{l}\text { Integrative: } \\
\text { transformational, } \\
\text { values-based }\end{array}$ & $\begin{array}{l}\text { Bennis (1994), Burns } \\
\text { (1982) }\end{array}$ & $\begin{array}{l}\text { To lead and be led is an interactive } \\
\text { process of interdependence. Leadership } \\
\text { transforms organizations by aligning } \\
\text { human beings and creating } \\
\text { organizational culture that encourages } \\
\text { free expression of ideas and opinions. }\end{array}$ \\
\hline $\begin{array}{l}\text { Results-based } \\
\text { leadership }\end{array}$ & $\begin{array}{l}\text { Nohria, Joyce and } \\
\text { Robertson (2003) }\end{array}$ & $\begin{array}{l}\text { The authors examined more than } 200 \\
\text { managerial procedures to determine } \\
\text { which of them are key to achieving } \\
\text { extraordinary results. There are four } \\
\text { primary processes: strategy, } \\
\text { implementation, culture and structure, } \\
\text { and four secondary processes: use to } \\
\text { talent, innovation, leadership and } \\
\text { fusion. }\end{array}$ \\
\hline $\begin{array}{l}\text { Cultural and holistic } \\
\text { leadership }\end{array}$ & $\begin{array}{l}\text { Senge (1990), Schein } \\
(1992), \quad \text { Wheatley } \\
(1992)\end{array}$ & $\begin{array}{l}\text { Leadership is related to the ability of } \\
\text { organization to create such environment } \\
\text { in which people can really grow as } \\
\text { human beings. Mutual alignment } \\
\text { releases synergy between individuals, } \\
\text { organizations and environments. }\end{array}$ \\
\hline
\end{tabular}

(Source: own processing)

Theoretical background concludes an overview of selected authors who understand leadership as a service. It concludes particular Greenleaf, Fraker and Spears (1996) a Frick and Spears (1996). These authors define leadership as a service to other people (employees, customers, community). Qualities of the leader are the ability to listen, empathy and development of the community.

However, the author doesn't want to examine only the question of management and leadership. The aim of this article is to explore these two approaches in the context of management philosophy, namely philosophy HOW and WHY. There are not too much literary sources that would examine various management practices through the prism of these philosophies. The author found only one source which partially describes these two types of management philosophy. Morel (2007) describes two types of companies, HOW companies and WHY companies. We can understand this description as a metaphor for different managerial procedures and practices. In other parts of this work, we shows what these management concepts mean and how are affected by the management and leadership. 


\section{OBJECTIVES AND METHODS}

The purpose of this article is to think about ways of management in business organizations. Author will examine two basic approaches to management and their impact on the effectiveness and organizational performance. These two basic approaches will be examined in context of organization culture, respectively management philosophy called as culture how and culture why.

Author will try to find answers to these questions:

1. What is better, to manage or to lead?

2. What does it mean how culture?

3. What are hidden cost of how culture?

4. Is there any alternative to how culture?

The first and second research questions fit into the area of performance measurement and two important discipline of management. In the third question, author discusses about the limits of how culture. The last research question deals with innovations in the management system. The effectiveness of the studied organizational model (called a "HOW" company) will be evaluated according to the performance capacity that companies can achieve by using rare resources (the intellectual and creative abilities of human beings).

\subsection{Quantitative research}

The article was supported by data gathered from quantitative research. Descriptive statistics was used as the method for processing the relevant data. Except it, the statistical correlation in contingency tables were analysed by Pearson statistics. P-value is being compared with standard 5\% confidence level. Lower value of tested criteria than confidence level leads to rejection of the null hypothesis. The null statistical hypothesis claims there is no association between variables. Calculations have been performed in Excel. Table 3 shows the details of this research.

Table 3 Characteristics of quantitative research.

\begin{tabular}{|ll|}
\hline Statistical sample: & $\begin{array}{l}\text { About } 850 \text { organizations were approached; fifty-six completed questionnaires } \\
\text { were returned. The frequency of organizations by size: }\end{array}$ \\
& \multicolumn{1}{c}{$\begin{array}{l}- \\
\text { small enterprises, } 16 \% \text { microenterprises. } \\
\text { The survey return was } 6.6 \% .\end{array}$} \\
\hline $\begin{array}{l}\text { Characteristics of the } \\
\text { respondent: }\end{array}$ & The respondents were employees at the level of middle and upper management. \\
\hline $\begin{array}{l}\text { Evaluation and form } \\
\text { processing: }\end{array}$ & $\begin{array}{l}\text { Data were organized into absolute and relative frequencies. Inductive statistics } \\
\text { were not used because of the small size of the statistical sample and the low } \\
\text { return of questionnaires. }\end{array}$ \\
\hline $\begin{array}{l}\text { Data collection } \\
\text { techniques: }\end{array}$ & Interactive questionnaire \\
\hline
\end{tabular}

(Source: own processing)

In light of the number of addressed respondents, the author attempted to ensure a sufficient representative sample. He estimated the necessary minimal sample size using the following relationship:

$$
n=\frac{Z^{2} p(1-p)}{d^{2}}
$$


If we require $90 \%$ reliability with a permissible error of $11 \%$, then the minimum number of surveyed respondents is the following:

$$
n=\frac{1,645^{2} * 0,25}{0,11^{2}}=\mathbf{5 5 , 9 0 9 6 0 7 4 4}
$$

According to the calculation above the minimum number of surveyed respondents for a representative sample is 56 . Of the total 850 companies contacted, exactly 56 surveys were returned.

\subsection{Case methodology}

To accomplishment of the current research, it has been used the case methodology. This is done to the main objective of finding and describing selected companies which use alternative management philosophy to the culture how. The author focused on three organizations with specific features of management, namely Toyota, FAVI, and W. L. Gore.

Author has analysed various information sources about these companies. Attention of author was focused on the attitudes of these organizations to the people and their motivation. Based on these attitudes, the author described the management model of these companies and their specific forms of organization.

\section{DISCUSION}

\subsection{To manage and/or to lead?}

Most of today 's companies prefer the term "to manage" than "to lead". As Table 4 shows, the relationship between leadership and management is characterized by the ratio of 1:2 in favour of management. The fact that most companies prefer management is not strongly dependent on the size of the company (as Figure 1 shows, managing and leading only closely approach each other in micro-enterprises). There is not a significant positive relationship between company size and management and leadership ( $\mathrm{p}$-value is higher than the confidence level).

Table 4 The attitude toward management and leadership

\begin{tabular}{|l|c|c|c|c|c|}
\hline & $\begin{array}{c}\text { Micro- } \\
\text { enterprises } \\
\text { in \% }\end{array}$ & $\begin{array}{c}\text { Small } \\
\text { enterprises } \\
\text { in \% }\end{array}$ & $\begin{array}{c}\text { Medium- } \\
\text { sized } \\
\text { enterprises in } \\
\%\end{array}$ & $\begin{array}{c}\text { Large } \\
\text { enterprises } \\
\text { in \% }\end{array}$ & p-value \\
\hline To manage & $44 \%$ & $75 \%$ & $75 \%$ & $82 \%$ & 0,765505984 \\
\hline To lead & $56 \%$ & $25 \%$ & $25 \%$ & $18 \%$ & 0,412114051 \\
\hline
\end{tabular}

(Source: own research) 
Figure 1 Management and leadership in context of company size.

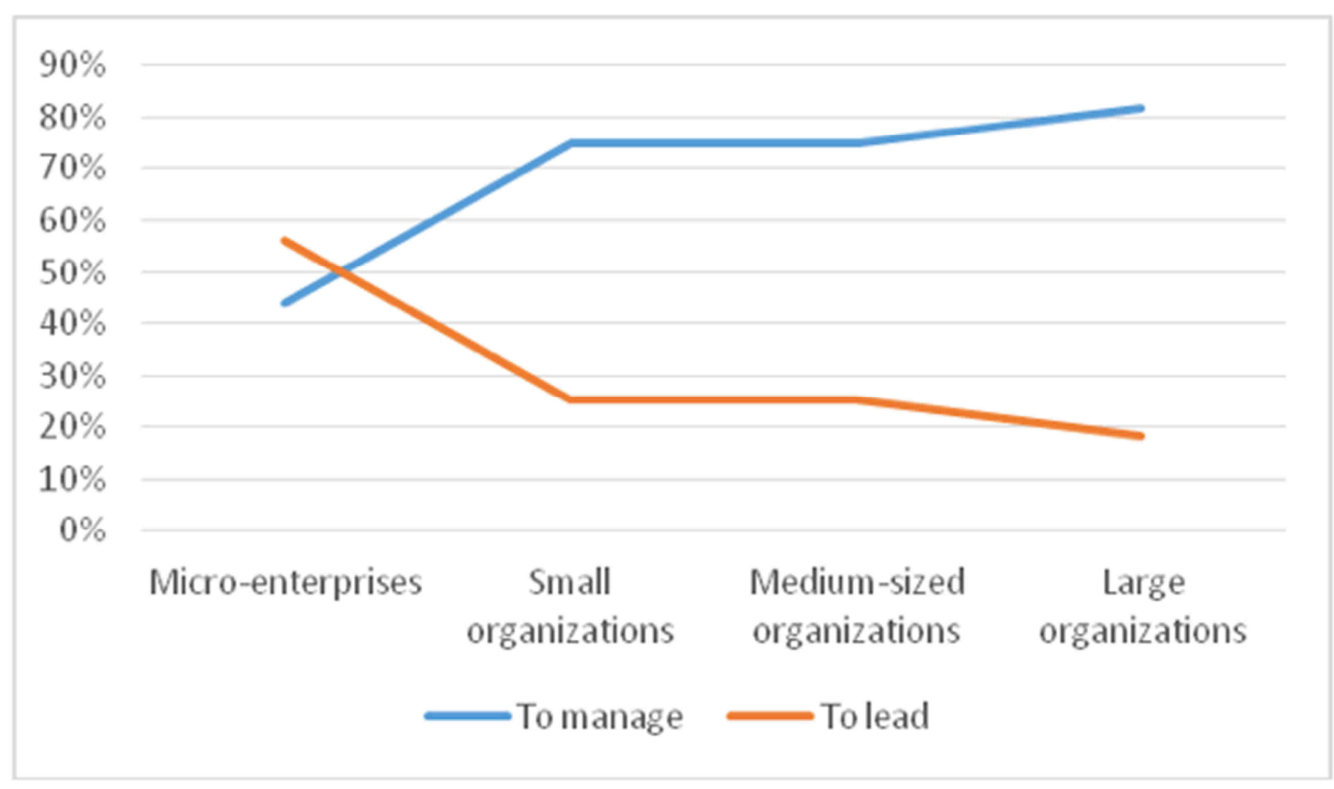

(Source: own research)

Managing is related to the concept of management as a discipline strictly focused on the results of measurement and thus it is more oriented on the results needed for the evaluation of its own performance. In terms of time, management examines factors that are bounded by a short-term perspective. This characterizes the lower limit of performance. On the other hand, the principle of leadership focuses on areas that are typical for the upper limit of performance. It contributes to the formation of results that fit into a long-term perspective. By using the words of Peter Drucker (2002) and Warren Bennis (1994), "to manage means to do things right, to lead means to do right things."

The performance of individuals, businesses, and society as a whole is directly affected by these two principles. Covey (2010) explains the importance of these two principles and their application in the context of a story about a group of people placed on a mysterious island. These people want to get to a particular destination. The planners attempt to create a plan and devise a strategy according to an old map. They measure time by a stopwatch and, with the help of organizers and supervisors, they watch over the ordinary workers using machetes in order to hack a way through the vegetation fast enough and in the desired direction. If they work according to the plan, they are rewarded appropriately; however, if not, they are punished accordingly. In this group, there are also people with leadership abilities. One of them climbs the tallest tree, looks around, and shouts: "We are on the wrong island!" The whole group is so busy with operative work that they do not hear him. The man continues to scream and therefore the managers (namely, the planners, organizers, supervisors) silence him since they are too engaged in their management procedures to listen. "Be silent," they say. "We are still moving forward." This metaphor does not involve only the diversity of the central principles of management but also touches on the principal foundation of performance, its concept and importance. Therefore, if the concept and meaning of performance change according to the approach to management, we can, according to Kouzes and Posner (2003), see two basic levels of performance in the meaning of the two rooted words, i.e. management and leadership. These two basic levels of performance are namely to manage things (in other words, to achieve the realization of things) and to get to certain point (or to focus). 


\subsection{What does it mean "HOW" Culture?}

Most large companies are organized on the basis of bureaucracy. This assumption is confirmed by own research, according to which eight out of ten large organizations operate on the basis of bureaucratic structures (see the table below). Analysis of the data also showed that there is not a significant positive relationship between company size and basic forms of organization.

Table 5 The prevailing organizational structure.

\begin{tabular}{|l|c|c|c|c|c|}
\hline & $\begin{array}{c}\text { Micro- } \\
\text { enterprises in } \\
\text { \% }\end{array}$ & $\begin{array}{c}\text { Small } \\
\text { enterprises } \\
\text { in \% }\end{array}$ & $\begin{array}{c}\text { Medium- } \\
\text { sized } \\
\text { enterprises } \\
\text { in \% }\end{array}$ & $\begin{array}{c}\text { Large } \\
\text { enterprises } \\
\text { in \% }\end{array}$ & p-value \\
\hline Bureaucracy & $33 \%$ & $33 \%$ & $71 \%$ & $82 \%$ & 0,273611444 \\
\hline Discipline & $67 \%$ & $67 \%$ & $29 \%$ & $18 \%$ & 0,133871793 \\
\hline
\end{tabular}

(Source: own research)

Figure 2 The prevailing type of organization.

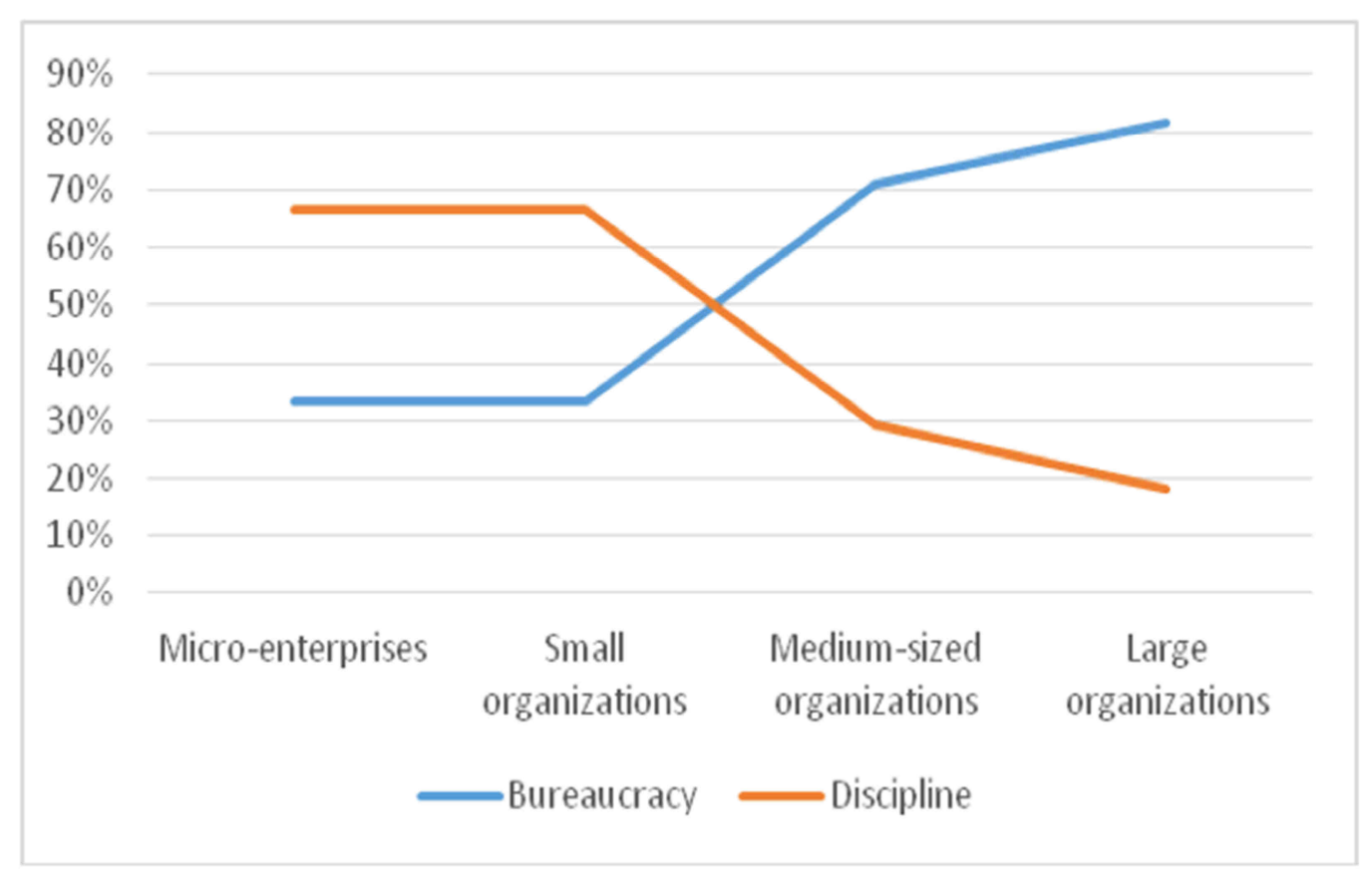

(Source: own research)

In this context, we can talk about "HOW" companies (Morel 2007). A "HOW" company is characterized as a bureaucratic institution in which people have to follow many regulations. The coherence of these companies is ensured by a dense network of commands and controls. The original assumption of this model is based on the unwillingness of people to work. Therefore, the aim of management is to tell people how to do their work (control) and constantly check their activities (manipulate). This model was created at a time when the world gave birth to the first modern business organization, i.e. in the middle of nineteenth century (Drucker 2002). For businesses at that time, this step meant an enormous increase in the productivity of manual workers and an enormous increase in their performance (Drucker 2001, 2002, 2004). Subsequently, this increase in performance economically transformed the whole of western society. According to 
Angus Madison (1991), from 1820 to 2001 gross income per capita in western countries increased about twenty times.

However, performance was primarily understood in terms of economic growth. A "HOW" company identifies itself with industrial age. According to this equation, profit is always in first place followed by people (Hamel 2013). Working conditions prevailing in "modern" companies at the height of the industrial revolution were very similar to the working conditions that prevail in manufacturing plants today - and not only in the developing world, with its "sweat shops" and child labour (Carney and Getz, 2013). In both cases, the same management model is implied. In this model, there are people who have the right to dictate (to give precedence) and people who have a duty to listen and obey (to conform).

\subsection{What are the hidden costs of the "HOW" culture?}

Nowadays, the topic of managing for "three percent" is becoming an increasingly discussed problem (Carney and Getz, 2013). These managers should introduce new rules that limit undesirable behaviour in $3 \%$ of employees. However, these rules have a subsequent negative effect on the remaining $97 \%$ of employees. We cannot be surprised by the traditional manager's thinking when talking for instance about the problem of theft in the workplace. In this case, the manager's suggestion might be to introduce measures to search all employees even though the problem is related to only a very small minority. The hidden social costs of this precaution would be the dampening of the initiative and involvement of all employees who were affected by this decision. And the fact that this is not unusual is demonstrated in research by Towers Perrin (2007 - 2008), which revealed that only $21 \%$ of employees were truly engaged (see also Hamel 2013). Research by the same company two years later revealed that only about $14 \%$ of employees felt engaged in their work (Tower Perrin, 2006; Hamel and Breen 2008). In the case of involvement while meeting corporate goals, the initiative of employees is even weaker, as shown in research by Haris Interactive. S. Covey (2010) makes reference to this research in his book The 8th Habit (see the table below).

Table 6 The involvement of workers while meeting targets.

\begin{tabular}{|c|c|}
\hline Questionnaire survey $(\mathbf{n}=\mathbf{2 3} \mathbf{0 0 0})$ & $\begin{array}{c}\text { Frequency of } \\
\text { positive answers }\end{array}$ \\
\hline $\begin{array}{c}\text { Do employees realize their organizational goals with } \\
\text { engaged passion? }\end{array}$ & $9 \%$ \\
\hline
\end{tabular}

(Source: Covey, 2010)

Low interest among employees indubitably leads to lost income. These kinds of costs arise from low performance capacity - employees simply do not perform extra tasks. The level of commitment among employees does not only affect the internal operations of the company. As illustrated in one study, $73 \%$ of customers went to a competitor due to the insufficient engagement of the company or its employees (Carney and Getz, 2013). Thus, when looking at the ability of companies to make a profit through the prism of engagement, we can observe interesting results. According to one survey (Tower Perrin, 2007), it is proven that companies with involved employees can increase their profits in the long-term (in the monitored companies, the average operating profit increased by $3.7 \%$ over a period of 3 years). However, the companies with uninvolved employees had reduced profits (in the same period, profits decreased by an average of $2 \%$ ).

Parkinson's First Law, which affects all organizations, increases with the size of the organization. As companies increase in size, they not only have to deal with bureaucracy (see Fig.2) but, 
moreover, also need to reflect on two related problems. The first problem is called creeping inefficiency. For a small company, the ratio of managers to other employees is typically 1:10 (9\% of employees are managers); one superordinate is in charge of 10 subordinates. For an organization with 10000 employees, due to Parkinson 's First Law, the number of leading employees and managers may increase up to 1250 employees and, therefore, the ratio of managers to other employees is reduced to $1: 8$ (11\% of employees are managers). Supposing that the manager's salary is three times higher than that of his subordinates, it can be quantified that the salaries of the managers represents $38 \%$ of the total wage costs. In the first example with small companies, the salaries of the managers represent $27 \%$ of total wages.

The second problem is related to the oppressive atmosphere that "HOW" companies create. Our own research shows that, in general, the so-called motivation pressure system predominates in companies, a structure which significantly contributes to a culture of fear and mistrust (see following figure). Motivation pressure system consists of force factors which comprise the survival factor, the fear factor and the money factor. Motivation push system consists of inspirational factors which comprise the enjoyment of work, praise, and self-realization. According to the values of the test criteria, we can state that there are not statistically significant differences between company size and difference factors of motivation.

Table 7 The prevailing motivation in practice.

\begin{tabular}{|l|c|c|c|c|c|}
\hline & $\begin{array}{c}\text { Micro- } \\
\text { enterprises } \\
\text { in \% }\end{array}$ & $\begin{array}{c}\text { Small } \\
\text { enterprises } \\
\text { in \% }\end{array}$ & $\begin{array}{c}\text { Medium- } \\
\text { sized } \\
\text { enterprises } \\
\text { in \% }\end{array}$ & $\begin{array}{c}\text { Large } \\
\text { enterprises } \\
\text { in \% }\end{array}$ & p-value \\
\hline Survival factor & $0 \%$ & $17 \%$ & $13 \%$ & $27 \%$ & 0,442678938 \\
\hline Fear factor & $0 \%$ & $8 \%$ & $8 \%$ & $9 \%$ & 0,701885758 \\
\hline Money factor & $67 \%$ & $83 \%$ & $88 \%$ & $91 \%$ & 0,93600229 \\
\hline Enjoyment of work & $22 \%$ & $17 \%$ & $21 \%$ & $9 \%$ & 0,873679018 \\
\hline Praise & $33 \%$ & $33 \%$ & $33 \%$ & $36 \%$ & 0,999022899 \\
\hline Self-realization & $56 \%$ & $33 \%$ & $25 \%$ & $36 \%$ & 0,298429096 \\
\hline
\end{tabular}

Figure 3 Factors of motivation in practice.

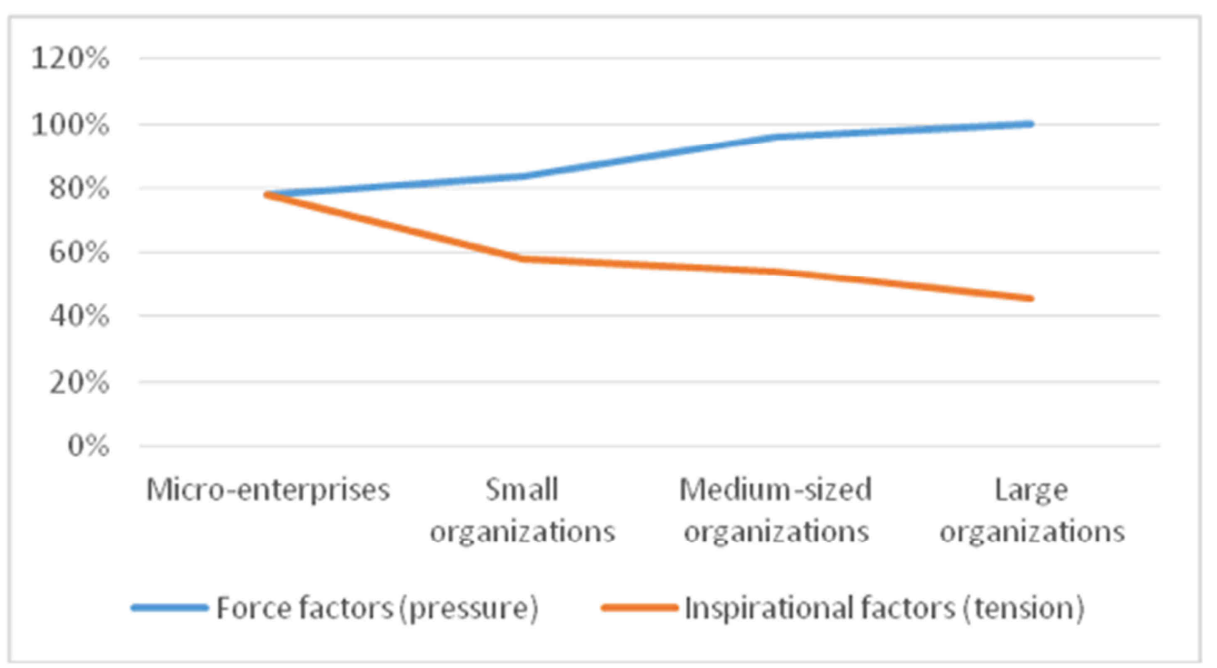

(Source: own research) 
The result of this atmosphere is so-called work-related stress (Atkinson 2000; Cartwight and Cooper 1997; Cortina et al. 2001; Wojcik 2001). Stress is activated by so-called stressors that cause a feeling of physical and psychological threat. Stressors can be personal conflicts, unrealistic goals, psychological bullying (being mocked or isolated, for example), a feeling of injustice, or various forms of force motivation (see Neuman, 2004). Stress may also appear in situations in which employees lose control over their work. Work becomes even more stressful when employees do not have sufficient freedom and space to make their own decisions. A sense of hopelessness emerges afterwards. In most cases, growing emotional stress leads to the collapse of goals and corporate vision. However, work-related stress affects not only large organizations. It is an unintended consequence of the "HOW" organizational culture, which can be applied in any organization regardless of its size. This culture prefers obedience before initiative. It appreciates uniformity (and agreement) instead of originality (and disagreement). Animals react to stress by escaping. People react to it simply by avoiding other people or demanding situations that cause stress. Therefore, it can be assumed that apathy at work is influenced by stress. According to The National Institute for Occupational Safety and Health, $40 \%$ of US employees are subject to stress at work (comparison with the motivation survey is essential and its results are shown in the table below). In light of this, there exists a legitimate suspicion that work-related stress causes so-called civilization diseases such as headaches, anxiety, stomach cramps, loss of energy, and many others. Therefore, it is not surprising that stress at work is the reason for approximately $80 \%$ of visits to general practitioners (Carney and Gets, 2013). What is then the total cost of work-related stress to the economy? In the case of the UK, it is estimated that, due to stress, the economy loses 40 million working days per year and seven billion pounds spent on health care (Handy, 1999). According to Gallup research in 2006, unconcerned behaviour and disengagement caused by stress creates an annual loss of productivity to the US economy amounting to 328 billion dollars.

\subsection{Is there any alternative to "How" culture}

Work-related stress is the most important source of hidden costs with respect to the traditional management model. Not only companies but also individual states have to deal with it. According to the US Bureau of Labour Statistics, the annual costs associated with work-related stress are 10 000 dollars for each individual employee. The study of work-related stress is closely related to the subjective feeling of the loss of control over a certain situation. So what does it actually mean in terms of the prevailing management system? "HOW" companies apply the technology of traditional management. It is based on the assumption that people are naturally lazy and do not want to work. Therefore, this model uses techniques that are intended to stimulate (activate) human beings to work. The backbones of this model are commands and controls that restrain the feeling of freedom (and responsibility). The "HOW" culture deliberately deprives its employees of the possibility to choose and thus increases the tendency of workers to experience stress. Companies that apply the traditional management model to the imaginary hierarchy of human capabilities, try to put an emphasis on obedience, diligence and intellect (see Fig. 4). 
Figure 4 The human capabilities in context of culture Why.

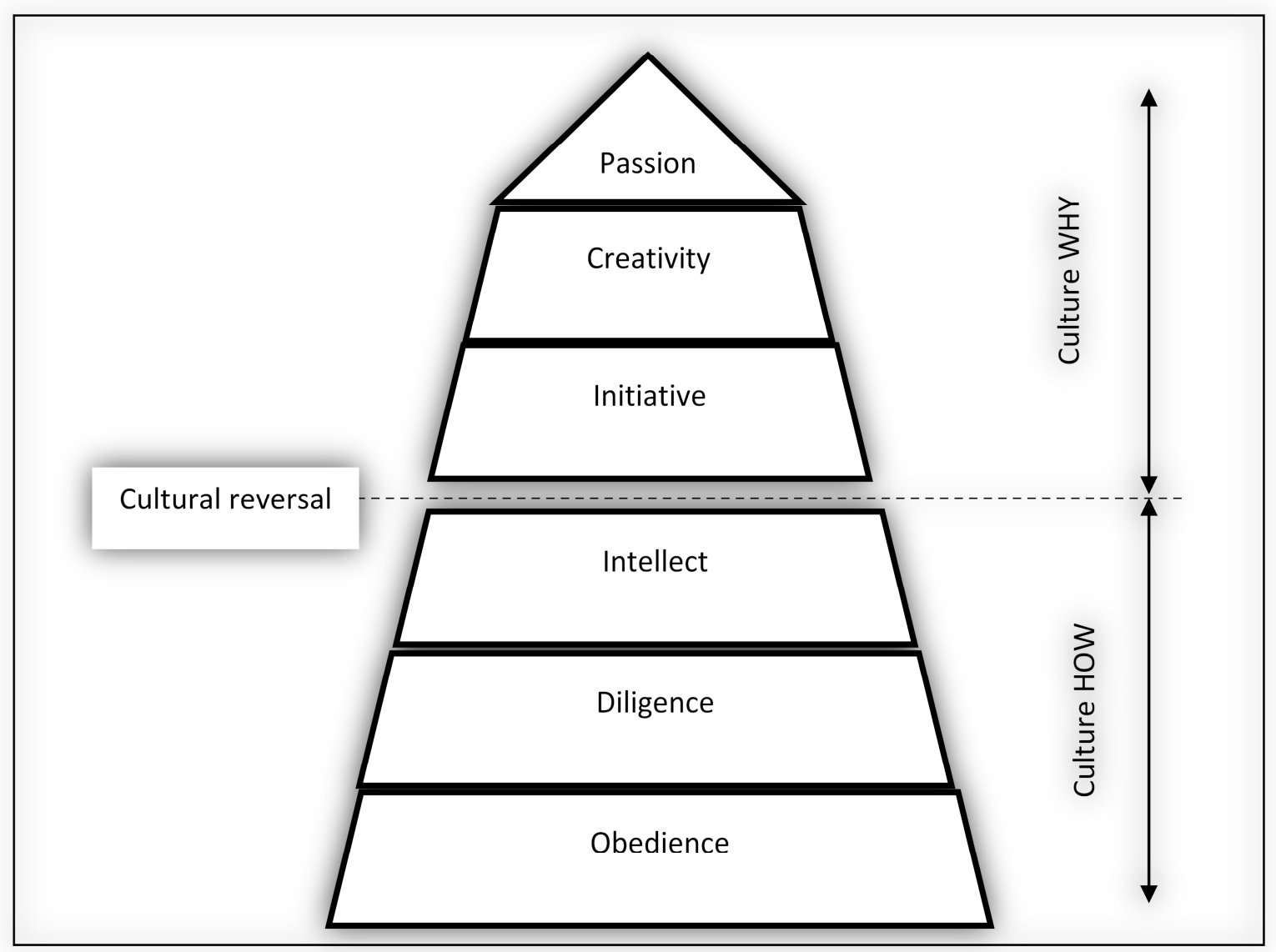

(Source: own processing.)

The hierarchy of human capabilities is similar to Maslow's pyramid of needs. For human beings, higher order needs are combined with greater motivation and satisfaction. For companies, human abilities are assessed according to the benefits of individuals to the whole group (personal performance). In the workplace, people can present themselves by various abilities as indicated in previous figure. When analysing the hierarchy of human capabilities, one question arises and that is whether, in addition to the tradition model, an alternative model of management can coexist. This alternative model is capable of placing human abilities above the level of obedience, diligence and intellect. In this imaginary model, words such as vanity or misappropriation would lose their meaning. Its aim is to humanize the organizational environment. Yet, an important question remains unanswered: are there any companies in the business environment that could become prototypes of companies applying the "WHY" culture?

\section{Cultural reversal.}

\section{Example 1: Bureaucracy with a human face}

When searching for a prototype of the "WHY" company, we can start with a brief analysis of Toyota. This company, straddling the border of both cultures, has an undoubtedly bureaucratic structure. All processes are planned to the smallest detail. Each employee is governed by predefined working procedures in order to complete a given task in the most efficient way. Consequently, very strong standardization is obvious. The central principle of the company is efficiency, which is ensured by a management technique known as management through procedures. All processes must be measured and controlled. What makes this company different from other similarly 
bureaucratic companies is its approach to ordinary employees. These ordinary employees are governed by procedures which are not constructed by executives but by the employees themselves. They have only one aim, which is perfection. Everyone is governed by the procedure only until he/she discovers a new and better procedure. Therefore, procedures are not enforced by the head of a certain department. Meeting the goals of procedures is dependent on the employees themselves. In the case of Toyota, effectiveness as a central value is accomplished by autonomy. This autonomy is used by employees and teams in order to adjust their working environment. Toyota believes in people's willingness to learn and this is the clear difference in contrast to other bureaucracies. Only through this idea is Toyota able to strengthen the authority of ordinary employees and create a cultural environment that values initiative.

\section{Example 2: Management philosophy based on asking question WHY}

An even more interesting example of the transition from the industrial model to a model of the WHY culture can be seen in FAVI. Originally it was a brass foundry which was typical of the industrial era until J.F. Zobrist became its director. After he joined the company he realized that a huge difference exists between the real economy (which includes opportunity costs) and the corporate economy (which works only with the explicit costs). He was inspired by an experience with one of his employees who wanted to change his old gloves for new ones. Zobrist found out that this exchange took place according to a clearly defined procedure. If a worker had damaged gloves, he had to show them to his manager, who would, in turn, furnish the worker with an order form for new gloves. Subsequently, the worker had to visit the store, where, on the basis of a correctly submitted application form, he received new gloves. The entire process of replacing old gloves with new ones took approximately 10 minutes. Zobrist calculated that the cost of operating the machine used by the worker was 100 dollars per hour. From this calculation, he determined that the changing of gloves resulted in opportunity costs of 17 dollars per hour. The gloves themselves cost less than 10 dollars!

This "economy" persuaded Zobrist to re-evaluate FAVI's original management philosophy. A new management philosophy was created, based on the idea that there are two types of firms: a "HOW" company and a "WHY" company. FAVI was an example of a "HOW" company. According to this model, it is usual to tell employees what to do, how long they should work, and when to go to work. Obviously, at FAVI, this behaviour had two consequences. Firstly, employees were evaluated according to all possible scales (number of hours worked, number of units produced, etc.) but not by the scale which is really important (customer satisfaction). Secondly, employees did not have the opportunity to influence their work routine. They were, figuratively speaking, bound by the chains of bureaucracy (a change had to be approved by a manager, who had to seek the approval of his manager, and so on, ad absurdum). By its transition from a "HOW" to a "WHY" company, FAVI had to learn to ask different questions from the ones they had been used to asking for decades. Thousands of HOW questions were replaced only by one question: WHY? The new emerging culture at FAVI no longer wanted to dictate to its employees about how they should do their work. It gave them greater freedom with the proviso that they had to learn to ask the question WHY? In the case of FAVI, asking the question WHY changed the overall focus of the company. As a result, its approach to performance changed, too. By using the question WHY, all corporate efforts began to orientate toward one central point - the customer. This cultural change turned attention away from narrow specialization, strict qualification, and a particular department towards the performance of the whole. And the consequences of this change for the company were radical. The time clock was removed. The new management concept led its employees not to consume time but to produce results. According to the new model, the HR department was closed due to the fact that people were no longer seen as machines but as human beings with specific psychological and physiological needs. Production also underwent several changes. It was restructured into units that formed self-managed teams with approximately 24 employees (an organization that was similar to 
the self-organization of workshops applied in the Bat'a Shoe Company). Every production team was responsible for a specific customer and a tailored product. The attempt to change the management model led not only to the invigoration of autonomy in individual workplaces but mostly to the elimination of a formal hierarchy. Each team was able both to choose its own leader and to dismiss its own leader. In general, the transition to the new model has brought significant results. From a long-term perspective, the company has been able to reduce prices to its customers by about three percent per year. Over a period of twenty-five years, it has never experience delays in delivery. It has become the European leader in the production of shift forks for the automotive industry. The size of its market share is reflected in the fact that one half of cars produced in Europe have shift forks produced directly by FAVI. Finally, the company has introduced entirely new products manufactured from brass, which have been exported to China.

\section{Example 3: Organizing without formal hierarchy}

W. L. Gore was named one of the "100 Best Companies to Work For" in the US by FORTUNE magazine. In addition, another magazine know as Fast Company magazine named Gora one of the most innovative companies in the world. This company focused on the production of more than 1,000 products in four divisions (electronics, textiles, consumer products, medical products) certainly attracts attention. It employs about 10,000 associates around the world. It was founded in 1958 by Wilbert (Bill) L. Gore. This chemical engineer left his employer, DuPont, to set up a new company that will be built on a unique organizational principles applied in the DuPont laboratories. Based on work experience from DuPont, Bill Gore have defined three important organizational principles on which he wanted to build his own company. First of all, people achieve the best results when are organized in relatively small groups. Secondly, these small teams mustn't be organized on the basis of the hierarchy. It means that team members must be equal. Only then they will identify with team goals and fully engage. Thirdly, the success of the projects is bound to the two important principles, cooperation and freedom. If people do not have the opportunity to choose what they want to do, they will not be motivated to achieve the best results.

Due to the nature of the company's founder, the organizational culture was influenced by Socratic Method, i.e. rather asking the questions than just giving the right answers. Thanks to this, communication was imbued with dialogue. Gradually, people working in this company has changed the terminology describing the reality of their company. In W. L. Gore, there are no employees. There are the associates. There are no job positions. There are the work commitments. There are no managers. There are the leaders. Leading position arises from the natural hierarchy which is given by the so-called a goblet of trustworthiness (i.e. the ability to meet the commitments) and a level of competence (knowledge and skills that are used in favour of others).

A typical feature of Gore's culture is also self-discipline. This cultural element replaces to a large extent the traditional management based on the commands and controls. Management model takes on the character of self-management. Each worker becomes a boss himself. The culture of W. L. Gore does not value obedience. This cultural element replaces to a large extent the traditional management based on the commands and controls. Management model takes on the character of self-management. Each worker becomes a boss himself. The culture of Gore does not value obedience. Conversely, the work environment encourages personal initiative and willingness to take risks. This willingness is reflected special management approach called leading to mistakes. The mistakes are not understood as a failure of the individuals, rather it is a source of growth and learning.

Nowadays we can see specific management model in this company which differs significantly from prevailing managerial practices. Gore doesn't work as a hierarchy where are decisions directed from top to bottom. It works as a lattice or network structure in which people can cooperate with anyone within the organization to get what they need to do their work. There are no job functions 
which would restrict the thinking and acting of workers. There are even no employees as was said previously. All the people working in this company are the associates (in other words partners). Each associate is co-owner of this company. W. L. Gore does not operate on the basis of subordination. This unique feature of Gore's management philosophy reflects the commitment and passion. Each associate commits to the work he wants to do. Associates discuss their tasks and duties with their colleagues. Work tasks can't be assigned to anyone, tasks can only be accepted in the form of a personal commitment. The company policy is: All harnesses are personal commitments. But it isn't anarchy. At the point when the associate commits to something (element of freedom), others expect from him (her) clear results (element of responsibility). In this management model, the freedom (the right to decide) connects with responsibility (the commitment to achieve results). And finally, W. L. Gore has no bosses. It has only leaders who are not appointed by top management, but rather their colleagues. Tribal leader becomes the person who is able to realize the challenging tasks and build efficient teams. It means that you will become the leader in Gore if others follow you.

Values and principles of W. L. Gore, confidence, freedom, responsibility, decency and waterline, created a work environment that releases the hidden human abilities which are initiative, creativity and passion. Due to these abilities, W. L. Gore achieves impressive innovation performance without planning. A number of innovations were born by a lucky coincidence, such as guitar string Elixir or Gore-Tex material. The dynamics of innovation drives free time at work. Each associate has a halfday off during the week. The working environment due to the initiative, creativity and passion resembles a marketplace of ideas in which proponents of new ideas have been competing for time of the best workers, and where workers are eager to join the most interesting projects. No surprise, therefore, that Gore enjoys excellent economic results and profit throughout its existence.

As evidently demonstrated by the experience of Toyota, FAVI and W. L. Gore, it is possible to create alternative management models in which the culture encourages initiative, creativity and passion in each employee. People engaged in these companies work in favour of the profit of their company beyond their work duties. This is so because these companies recognize the huge potential that is hidden in people. The cultural feature of this model is the belief that people together know more that the smartest person among them. And what is the purpose of this model? To manage as little as possible - in other words, to allow people to learn from their own mistakes.

\section{CONCLUSION}

The most serious consequences of the traditional "HOW" management model are the paralyzing of involvement, the loss of income, and work-related stress. These hidden costs are caused by one factor, namely the lack of employee involvement in the decision-making structures of organizations. "HOW" companies do not trust their own employees and are not willing to pass a large proportion of "management" responsibilities onto their shoulders. Consequently, this causes the suppression of the intellectual potential of companies. Therefore, most companies achieve low performance capacity. An alternative to this management model is a management system based on the "WHY" culture. In the Brazilian company SEMCO, this procedure is called participative management (Semler 2011). The principal value espoused by companies that begin to apply this model is freedom (and responsibility). In these companies, bureaucracy is replaced by a culture of discipline. Employees in this culture are encouraged to experiment (examples of companies with such a culture are FAVI, W. L. Gore) and to build working relationships based on personal commitments. This latter feature is evident in companies such as W. L. Gore or also Morning Star. As demonstrated in several research projects (e.g. see Collins, 2008), the difference between good and great companies is related to the organizational ability to balance on the fine edge between order (responsibility) and chaos (freedom). Overall, this means to build a culture based on personal responsibility in which people are given considerable freedom to realize their own ideas. To create a 
working environment in which workers are given freedom is not easy. It requires the ability of organizations to build a shared vision, to determine operating principles, and to define core values.

Looking further into the business environment, we can see that there exist many interesting companies that could become prototypes of the "WHY" company. Features of why culture can exist in organizations that use innovative management model built on the principles of trust, freedom and responsibility. Some of these characteristics were seen by other authors at the companies, which include Semco, Morning Star, Google, Apple, Whole Foods Market, IDEO, Harley-Davidson or also SOL. Therefore, further research will be focused on the analysis of companies that apply the principles of trust, freedom and responsibility, these being the typical values of such a new and innovative management model.

\section{REFERENCES}

Argyris, C. (1957). The individual and organization: Some problems of mutual adjustment. Administrative Science Quarterly, 1-24.

Atkinson, W. (2000). Managing Stress, Electrial World, 6, 41-42.

Bennis, W. (1994). An Invented Life: Reflections On Leadership And Change. New York: Basic Books.

Bennis, W., Managing the Dream: Leadership in the 21st Century. Training: The Magazine of Human Resource Development. 1990, vol. 27(5), s. 44-46.

Burns, M. J. (1982). Leadership, New York: Harper.

Carney, M., B., \& Getz, I. (2013). Svoboda v práci. Praha: PeopleComm.

Cartwight, s., Cooper, C., L. (1997). Managing Workplace Stress. California: Sage.

Collins, J. (2008). Good to Great. Praha: Grada Publishing.

Cortina, L., M., Magley, V., J., Williams, J., H., Langout, R., D. (2001). Incivility in the Workplace: Incidence and Impact. Journal of Occupational Health Psychology, 6, 64-80.

Covey, R., S. (2010). The 7 Habits of Highly Effective People. Praha: Management Press.

Covey, R., S. (2010). The 8th Habit: From Effectiveness to Greatness. Praha: Management Press.

Drucker, F., P. (2004). Fungující společnost. Praha: Management Press.

Drucker, F., P. (2002). To nejdůležitější z Druckera v jednom svazku. Praha: Management Press.

Drucker, F., P. (2001). Výzvy managementu pro 21. století. Praha: Management Press.

Frick, D., \& Spears, L. (1996). On becoming a servant leader: The private writings of Robert K. Greenleaf, San Francisco: J ossey-Bass Publishers.

Galagan, P. A. (1998). eter Drucker. Training \& Development, 52, 22-27.

Gallup Study. 2006. Engaged Employees Inspire Company Innovation. Gallup Management Journal. $\quad$ http://gmj.gallup.com/content/24880/Gallup-study-Engaged-Employees-InpsireCompany.aspx

Gardner, J. W. (1990). On leadership. New York, NY: The Free Press.

Greenleaf, R. K., Fraker, A. T., \& Spears, L. C. (1996). Seeker and servant: Reflections on religious leadership, (Vol. 157). Jossey-Bass Inc Pub.

Hamel, G. (2013). What Matters Now. Praha: PeopleComm.

Hamel, G., Breen, B. (2008). The Future of Management. Praha: Management Press.

Handy, CH. (1999). The Hungry Spirit. Praha: Management Press.

Johnson, M. (1996). Taking the lid off leadership. Management Review, 85(11), 59..

Kotter, J. (2000). Leading Change. Praha: Management Press.

Kotter, J. (1990). What Leaders Really Do. Harvard Business Review, 68, 103.

Kouzes, J., Posner, B. (2003), The Leadership Challenge. San Francisco: Jossey-Bass.

Lazarus, R., S. (1984). Stress, Apraisal, and Coping. New York: Springer.

Madison, A. (1991). Dynamic Forces in Capitalist Development: A Long-Run Comparative View. New York : Oxford University Press. 
Mariotti, J. (1998). Leadership matters: so does the" soft" side of management. Industry Week, 247(6), 70.

Maslow, A. H. (1965). Humanistic science and transcendent experiences.Journal of Humanistic Psychology, 5(2), 219-227.

McGregor, D. (1960). The human side of enterprise. New York, 21, 166.

Morel, M. (2007). FAVI: L'entreprise qui croit que l'homme est bon. Paris: Humanisme \& Organisations.

Neuman, J. H. (2004). Injustice, stress, and aggression in organizations. The dark side of organizational behavior, pp. 62-102.

Nohria, N., William, J., \& Roberson, B. (2003). What really works. Harvard Business Review, 81(7), 42-53.

Peters, T. (1994). Thriving on chaos. New York: Alfred A. Knopf.

Schein, E. H. (1992). How can organizations learn faster?: the problem of entering the Green Room. Alfred P. Sloan School of Management, Massachusetts Institute of Technology.

Semler, R. (2011). Maverick!. Praha: PeopleComm.

Senge, P. (1990). The fifth discipline: The art and practice of the learning organization. New York: Currency Doubleday.

Sisodia, R, Wolfe, D.B and Sheth, J. (2007). Firms of Endearment: How World-Class Companies Profit from Passion and Purpose. Wharton School Publishing, Upper Saddle River, NJ.

Towers Perrin. Global Workforce: Global Report (2007-2008), [online]. [cit. 2015-01-20], https://c.ymcdn.com/sites/www.simnet.org/resource/group/066D79D1-E2A8-4AB5-B62160E58640FF7B/leadership_workshop_2010/towers_perrin_global_workfor.pdf

Towers Perrin. 2007. Engaged Employees Drive the Bottom Line, 2007. [online]. [cit. 2015-01-20], http://www.twrcc.co.za/Engaged\%20employees\%20drive\%20the\%20bottom\%20line.pdf

Towers Perrin. 2006. Winning strategies for a global workforce: Attracting, retaining, and engaging employees for competitive advantage. Valhalla, NY: Author.

Weathersby, G. B. (1999). Leadership vs. management. Management Review, 88(3), 5.

Wheatley, M. J. (1992). Leadership and the new science: Learning about organization from an orderly universe. San Francisco: Berrett-Koehler.

Wojcik, J. (2001). Cutting Costs of Stress. Business Insurance, 13, 1-2.

Zaleznik, A. (1977). Managers and leaders: Are they different. Harvard business, 55, 67-78. 